\title{
Colonial Spain in Africa: Building a Shared History from Memories of the Spanish Protectorate and Spanish Guinea
}

\author{
Yolanda Aixelà-Cabré \\ Consejo Superior de Investigaciones Científicas. Institución Milá y Fontanals (IMF) \\ e-mail: yaixela@imf.csic.es \\ ORCID iD: http://orcid.org/0000-0002-4333-9739
}

Submitted: 17 February 2020. Accepted: 28 June 2020

\begin{abstract}
This article compares Spanish, Riffian and Equatorial Guinean memories to address Hispano-African history and understand their colonial experiences. Examining Africans' voices in the 21st century from Postcolonial and Decolonial perspectives allows us to uncover Spanish colonial rhetoric about Moroccans and Equatorial Guineans and the racialised inequalities they had to face during the Spanish settlement. This approach shows the urgency of conciliating different versions and promoting a decoloniality process for Spain: the colonial past must be rebuilt for all and different sociocultural encounters must be rewritten to include expressly African voices. The final aim is to offer a contested version of Spanish colonial history in 20th century Africa, promoting a more shared social colonial history.
\end{abstract}

KEYWORDS: Hispano-African history; Decoloniality; Colonial memories; Shared history; Spanish Protectorate; Morocco; Spanish Guinea; Equatorial Guinea.

Citation / Cómo citar este artículo: Aixelà-Cabré, Yolanda (2020) "Colonial Spain in Africa: Building a shared history from memories of the Spanish Protectorate and Spanish Guinea" Culture \& History Digital Journal, 9 (2): e017. https://doi. org/10.3989/chdj.2020.017

RESUMEN: La España colonial en África: construyendo una historia compartida desde las memorias del Protectorado español y de la Guinea Española. - Este artículo compara las memorias españolas, rifeñas y guineoecuatorianas para acercarse a la historia hispano-africana y comprender sus experiencias coloniales. El análisis de las voces africanas contemporáneas desde el siglo XXI formulado desde una perspectiva Postcolonial y Decolonial permite desvelar la retórica colonial española sobre marroquíes y guineoecuatorianos, así como las desigualdades racializadas que tuvieron que afrontar durante el asentamiento español. El enfoque muestra la urgencia de alentar versiones conciliatorias que promuevan un proceso de decolonialidad en España: el pasado colonial debe ser reconstruido para todos, reescribiendo diferentes encuentros socioculturales que incluyan expresamente voces africanas. El objetivo final es ofrecer una versión contestada de la historia colonial española en el África del siglo XX y promover una historia social de la colonia más compartida.

PALABRAS CLAVE: Historia hispano-africana; Decolonialidad; Memoria colonial; Historia compartida; Protectorado español; Marruecos; Guinea Española; Guinea Ecuatorial.

Copyright: (C) 2020 CSIC. This is an open-access article distributed under the terms of the Creative Commons Attribution 4.0 International (CC BY 4.0) License. 


\section{SPANISH VOICES AND AFRICAN MEMORIES}

The goal of this article is to counterbalance contemporary Spanish voices with Moroccan and Equatorial Guinean memories in order to renew the foundations of Hispano-African colonial history. As Spain is one of the few western European countries that has not promoted public reflection about its colonial past in Africa, the task is imperative (Rizo, 2012, p. 32; Santamaría Colmenero, 2018, p. 446; Fernández Parrilla and Cañete, 2019, p. 113). This goal, formulated from a Postcolonial and Decolonial Studies perspective, is grounded on the one hand in Santos and Meneses's (2014) epistemologies of the South, ${ }^{1}$ which Quijano (2014) argues reveal the continuity of colonialism in the form of the "coloniality of power and knowledge" - as Mignolo (2004, p. 668) points out, while colonialism may be understood to be a relic, coloniality is very much alive. In this article I will focus on historical knowledge and its impact on Spanish colonial memories in order to encourage a shared social history: following the profound theoretical and methodological work in Subaltern Studies of Thompson (1988) and Spivak (1988), I will highlight the need to move towards a history "about the everyday life and experiences of common people" (Lee, 2005, p. 3). By recovering epistemologies of the South from Moroccans and Equatorial Guineans we can contrast their versions of daily life with those of the Spanish and thereby enrich the accounts of Spain's colonial past; by questioning the most widespread Spanish rhetoric, a path opens up towards building and consolidating more plural shared stories. The final goal is to put versions of the Spanish colonial past in Africa into circulation that give all voices equal weight and lay the foundations for a more consensual history. According to Santos and Meneses (2014, p. 16) the epistemologies of the South should enhance horizontality, as they are "an invitation to a broad recognition of the world's knowledge experiences, which include, after their reconfiguration, the knowledge experiences of the Global North".

The starting point for this article is the complementarity between history and memory. These are understood as lived oral experiences by the ethnographic tradition that eventually recognised the importance of historical analysis of social processes (Evans Pritchard 1961, Sahlins 1993), gathering oral records (Vansina 1961), questioning colonial memories (Stoler and Strassler 2000), using colonial archives (Stoler 2002), and the theft of Western historical writing (Goody 2007), to mention a few of the thematic spaces that have strengthened the link between memory and history in anthropology. In this article, colonial memories are understood as oral and written testimonies and personal stories from a given time and a specific context that allow, as Stoler and Strassler (2000, p. 4) have pointed out, "an explicit engagement with the nature of colonial memories not only with what is remembered and why, but with how the specifically 'colonial' is situated in popular memory at all", because what is relevant is that the "Marking off of a colonial 'then' from a postcolonial 'now' flattens out a set of intervening and cross-cutting points of reference" (Stoler and Strassler 2000, p. 9). Elsewhere, I have noted the necessity of "the circulation of new narratives of otherness that balance the past from a more egalitarian perspective which restores memories, including peripheral versions, changing centralities, and favouring intercultural encounters that subvert the stereotypes" (Aixelà-Cabré, 2018, p. 129).

An excellent example of the fruitful combination of memory and history in the scientific production on Morocco was offered by the ethnographer Boum. In Memories of Absence (2013) he studied the way four generations of Moroccan Jews remembered the Jewish community, research that straddles anthropology and history. Before that, Schroeter $(1988,2002)$ had done robust work on Jews in Morocco, after long warning researchers to be conscious of the uses of memory (Schroeter, 2018) 2 . In the case of Equatorial Guinea, the writer Donato Ndongo (1977) reconstructed the country's colonisation by blending the versions and experiences of Equatorial Guineans into an extraordinary feat of colonial memory and history. Both examples challenge the supposedly difficult fit between memory and history in my case studies. It is a debate that authors such as Huyssen (2007, p. 8) assumed had already been won when they argued that memory should not be trivialised by historians, as the intensity of the discourses of memory are "characteristic of contemporary culture in the most diverse places in the world" (Huyssen, 2007, p. 4) . $^{3}$

This article therefore seeks to reconstruct colonial history out of the memories and personal experiences of Spaniards, Moroccans and Equatorial Guineans, with the awareness that memories have many biases and are clearly marked by a historically constructed otherness, as noted by Mudimbe (1988, p. xi), Castro-Gómez and Grosfoguel (2007, p. 31), and Mignolo (2018, p. 106).

A need therefore exists to gather voices to contrast Spanish versions of everyday life with Moroccan and Equatorial Guinean memories and experiences. Spain's missing colonial history and the concerning overlaps between the colonial rhetoric of otherness and Spanish aims in Africa and the memories and practices of Spaniards during the colonial era suggest a linkage that reinforces certain coloniality effects towards both communities in Spain ${ }^{4}$.

This review of the colonial past will be carried out through the selection of representative testimonies recalling what daily life was like in the colonies. In this way we can place into circulation the narratives that structured the relations between Spaniards and Moroccans and Equatorial Guineans, as well as testing whether Spanish colonial rhetoric persists among former settlers in $21^{\text {st }}$ century Spain. The result may help overcome Spain's invisibility in Africa and the stigma created by Spanish preconceptions about the Hispano-African colonial past; it may help banish the imperial nostalgia (Lorcin, 2014, pp. 146-149) that could obstruct the consolidation of a more balanced and shared social colonial history.

Previous studies comparing Spanish colonial policies in the Spanish Protectorate and Spanish Guinea ${ }^{5}$ have not 
contrasted the justifications employed by Spanish civilians during the occupations (Martínez Carreras, 1993; Salafranca, 2001; Martín Corrales, 2002, 2008; Sánchez Gómez, 2006; Martín Márquez, 2011; Álvarez Chillida and Martín Corrales, 2013; Aixelà-Cabré, 2017). Commendable work has been done in Literary Studies, analysing Equatorial Guinean and Moroccan voices through literature (Mbare Ngom, 1996; Ndongo, 2000, 2010; Fernández Parrila, 2006; Otabela and Onomo-Abena, 2009; Abrighach, 2015; Borst and Gallo González, 2019), but Spanish civilian memories have not been revised. Moreover, there has been no systematic research on Spanish civilian memories in Equatorial Guinea and Morocco, aside from a few interesting pieces of work such as those by Nerín $(1999,2019)$, Rodríguez Mediano (1999), Iliescu (2017) and AixelàCabré (2019b). Their profuse explanations of themselves, especially in books and journals, provide no Moroccan or Equatorial Guinean points of view. Moreover, Moroccan and Equatorial Guinean colonial memories have barely been gathered, even though they contradict Spanish interpretations and data (Ndongo, 1977; Aziza, 2003). Coloniality from a gender perspective will also be included, as the colonial experiences of women and men differed. As Walsh described (2018, p. 16), "Decoloniality has a history, herstory, and praxis of more than 500 years. From its beginnings in the Americas, decoloniality has been a component part of (trans)local struggles, movements, and actions to resist and refuse the legacies...".

Retelling the common Hispano-African past to incorporate African versions is necessary, but opportunities are declining dramatically due to the advanced age of the witnesses. It is also disturbing that the Spanish state has not encouraged an extensive review of its presence, accepted its mistakes and made them clear to the Spanish public. It has prior experience of this in relation to its past in America ${ }^{6}$. The failure to rethink Spain's past and its colonial memory has reinforced a kind of imperial fantasy (Delgado 2014, p. 74) that took root in the Spanish state (Aixelà-Cabré, 2018, p. 38), as Buettner (2016, p. 423) has demonstrated for other European metropoles. For Kamen (2006, p. 14) "there are few people so married with imaginary visions of the past as the Spanish".

The ultimate aim of this work is nothing less than a revision of Hispano-African pasts, promoting a renewed approach to a more shared colonial history, using epistemologies from the South in order to favour the construction of a more consensual past and plural memory for Spain in Africa.

\section{METHODOLOGY}

The research has combined different methodologies typical of Cultural Anthropology and Anthropology of History: oral history has been used, together with the study of various documentary and archival sources; fieldwork was based on participant observation and informal and semi-structured interviews conducted in a multisited ethnography framework (Marcus, 1995). The oral sources were compiled following the work of Thompson (1988) and Jelin (2002), as the goal was to recover life stories that allowed different historical periods to be constructed from the informants' experiences, giving greater weight to the ethnographic approach, as Palmié and Stewart (2019) propose. The study of Equatorial Guinea (specifically on the mainland) began in 2015, although my intense fieldwork in Equatorial Guinea took place from 2004 to 2012, including several stays each year, and multisited ethnography in African and European countries. For this research, I interviewed six Spaniards and 17 Equatorial Guineans, some over a number of years (for details see the notes on each informant), I analysed the Resúmenes Estadísticos del Gobierno General de los Territorios Españoles del Golfo de Guinea from 1942 to 1964 and studied the Colección Giménez Ferrer (IMFCSIC), where I was able to read the words of Irmina Margenat and Ramón Reig, a couple that lived in Equatorial Guinea from 1927 until 1965. The study of Al-Hoceima started in 2015, but my long experience of fieldwork in Morocco began in 1991. In this research, I have interviewed 35 people: nine Spaniards, 24 Riffians, and two from other parts of Morocco. I have also studied files in the Archivo General de la Administración (Alcalá de Henares); 20 of the 50 issues of the postcolonial newsletter Heraldo de Alhucemas (numbers 25 to 45); some censuses of the Spanish Protectorate during the colonial period; and different publications by former settlers such as Rubio and Alfaro (1992) and Roman (1994). For both case studies, throughout the article I recommend watching the NO-DO Spanish newsreels from the Franco dictatorship, which help contextualise the geographical areas studied, the unequal relations between Spaniards and Moroccans and Equatorial Guineans, and the changes that took place in colonial narratives towards the end of colonisation.

\section{CONTEXTS OF STUDY}

This work focuses on the study of the two most important Spanish colonies in Africa, in what are now Morocco in North Africa and Equatorial Guinea in Sub-Saharan Africa. Both stood out for being the only Spanish colonies of settlement on the continent.

Morocco's colonisation lasted from 1912 to 1956 and took the form of a protectorate. Under French and Spanish rule, the country was split in two, the north under Spanish supervision and the south under French tutelage. The capital of the Spanish Protectorate was Tétouan, a city that shared prominence with the Spanish enclaves in Africa, Ceuta and Melilla, locations through which a large part of the Spanish civilian population that settled in the country during the colonial regime travelled.

The Spanish Protectorate will be analysed using the case of Al-Hoceima. The main city in the Rif region, AlHoceima was founded by Spaniards in 1927 and mainly populated by them until the 1950 s, except for a few Moroccan potentates and the small community of Moroccan Jews. As can be seen in tables 1, 2 and 3 below, the high degree of Spanishisation of this city was exceptional 
Table 1. Population of Morocco: 1933 Census

\begin{tabular}{|c|c|c|c|c|}
\hline & Total & Spanish & European & Moroccan \\
\hline $\begin{array}{l}\text { Spanish and French Protectorate of } \\
\text { Morocco }\end{array}$ & $4,506,000$ & - & 95,000 & $4,411,000$ \\
\hline $\begin{array}{l}\text { Population of the Spanish } \\
\text { Protectorate }\end{array}$ & 707,288 & $4.6 \%(32,804)$ & $0.1 \%(605)$ & $95.3 \%(673,876)(2 \%$ Jewish $)$ \\
\hline
\end{tabular}

Source: Compiled by the author. Comisión Histórica de las Campañas de Marruecos 1935, volume I (p. 285).

Table 2. Population of the Rif

\begin{tabular}{|c|c|}
\hline $\mathbf{1 9 3 3}$ & $\mathbf{1 9 5 0}$ census \\
\hline 179,928 & 154,602 \\
\hline
\end{tabular}

Source: Compiled by the author. Comisión Histórica de las Campañas de Marruecos 1935, volume I (p. 143). Spanish population census $31 / 12 / 1950$.

Table 3. Population breakdown for three cities in the Moroccan Protectorate: 1933 Census

\begin{tabular}{|l|c|c|c|}
\cline { 2 - 4 } \multicolumn{1}{c|}{} & Spanish & Muslim & Jewish \\
\hline Villa Alhucemas & $91 \%(3,657)$ & $8 \%$ & $1 \%$ \\
\hline Tétouan & $24 \%(11,481)$ & $63 \%$ & $13 \%$ \\
\hline Alcazarquivir & $10 \%(2,605)$ & $80 \%$ & $10 \%$ \\
\hline
\end{tabular}

Source: Compiled by the author. Comisión Histórica de las Campañas de Marruecos 1935, volume I, (p. 285).

compared to other cities of the Spanish Protectorate. Spanish people made up $91 \%$ of the population of Al-Hoceima in 1933, while in the protectorate as a whole they accounted for just $4.6 \%$. The case of Al-Hoceima is especially interesting, as it presents new versions of the Spanish colonisation of Morocco beyond the extended Hispano-Moroccan brotherhood narrative studied by Mateo Dieste (2003), a narrative that was absent from Al-Hoceima until independence (Aixelà-Cabré, 2019b). It is not accurate to say that Spaniards attempted to develop direct bridges with Moroccans as the rhetoric proposed - they already exerted complete socio-political control of its urban context and the Rif area (Aixelà-Cabré, 2019b, p. 208).

The Spanish colonisation of Equatorial Guinea was stipulated in the 1777-1778 Treaty of El Pardo, although the country's effective colonisation was delayed for decades. In 1843, the city of Santa Isabel was founded on the island of Fernando Póo by British missionaries; the very gradual Spanish settlement grew more significantly after 1880 when the island centralised the cacao, wood and coffee plantations. In the case of the mainland territory, the effective colonisation began to materialise after the foundation of the city of Bata in 1905, which was elevated to capital of the area and was the second-most important city in the country. The most significant socio-political changes in the colony were its provincialisation in 1959 and its categorisation as Autonomous Region in 1963.

Mainland Spanish Guinea (known as Río Muni) will be studied, along with the regional capital, the city of Bata. But I will also take into account the experiences in the colonial settlements of Fernando Póo and, specifically, Santa Isabel. In fact, unlike Al-Hoceima, which was an exception in the Spanish Protectorate, the colonisation of Río Muni presents significant overlaps and continuities with that of Fernando Póo, even though the mainland was colonised later than the island. One of the main characteristics of the Spanish colonisation of the Spanish Guinea was how few Spaniards settled there compared to the Protectorate, but this reality did not mean Spanish control, influence or exploitation were less effective. As Table 4

Table 4. Population of the Spanish Territories of the Gulf of Guinea

\begin{tabular}{|l|c|c|c|c|c|}
\cline { 2 - 5 } \multicolumn{1}{c|}{} & Year of census & Total population & "White" population & Spanish population & African population \\
\hline $\begin{array}{l}\text { Spanish Territories of } \\
\text { the Gulf of Guinea }\end{array}$ & 1942 & 157,891 & $2.6 \%(4,124)$ & $1.9 \%(3,068)$ & $97.4 \%(153,767)$ \\
\hline Mainland territory & 1942 & 130,049 & $0.6 \%(805)$ & - & $99.4 \%(129,244)$ \\
\hline Bata City & 1942 & 848 & $27.7 \%(235)$ & - & $72.3 \%(613)$ \\
\hline $\begin{array}{l}\text { Spanish Territories of } \\
\text { the Gulf of Guinea }\end{array}$ & 1950 & 198,663 & $2 \%(3,937)$ & $1.8 \%(3,595)$ & $98 \%(194,726)$ \\
\hline Mainland territory & 1950 & 156,176 & $0.9 \%(1,497)$ & - & $99.1 \%(154,679)$ \\
\hline Bata City & 1950 & 6,790 & $9.1 \%(617)$ & & $90.9 \%(6,173)$ \\
\hline
\end{tabular}

Source: Compiled by the author. Resúmenes Estadísticos del Gobierno General de los Territorios Españoles del Golfo de Guinea, 1945 (pp. 30-31). Resúmenes Estadísticos del Gobierno General de los Territorios Españoles del Golfo de Guinea, 1949 (p. 29). Resúmenes Estadísticos del Gobierno General de los Territorios Españoles del Golfo de Guinea, 1953 (pp. 26-27). Censo de Población de las Posesiones del Golfo de Guinea, volume I, Breakdown by province (p. 327). Resúmenes Estadísticos del Gobierno General de los Territorios Españoles del Golfo de Guinea, 1943 (p. 5) and 1954-1955 (p. 28). Resúmenes Estadísticos Región Ecuatorial, Provincias de Fernando Póo y Río Muni, 1964 (p. 378 ). 
shows, in 1942 only $0.6 \%$ of the population located on the mainland were European $(2.6 \%$ in the colony as a whole). As a powerful minority, Spaniards left a deep imprint on the social, political and linguistic spheres in Spanish Guinea, in some ways more strongly than in the Spanish Protectorate.

The Riffian city studied was far from typical of the Spanish settlements in colonial Morocco. Nevertheless, similarity emerges when Al-Hoceima is compared to Spanish Equatorial Guinean settlements, because, just as in the Spanish Territories of the Gulf of Guinea, the Spanish interest in coexisting with the population was non-existent and there were strong parallels between the distant, hierarchical social relationships established by Spaniards with Riffians and those with Equatorial Guineans on the mainland.

\section{SPANIARDS IN THE COLONIES}

The emigration of Spaniards to the colonies was an opportunity for economic improvement for them, but also an escape route for many Republicans from the Civil War and the Spanish post-war period (López García, 2007, 2008). My ethnographic research showed that the Spanish settlement of the Rif region and Spanish Guinea fitted two distinct migratory models: family emigration in the case of Al-Hoceima, and men travelling alone in the cases of Fernando Póo and the mainland region of the Spanish Territories of the Gulf of Guinea (until the 1940s). It is worth saying that the Spanish settlement of Al-Hoceima was a relatively fast process, as in barely 15 years the city went from a population of a few hundred people to various thousands (see Table 5). ${ }^{7}$

Table 5. Population of the Spanish Protectorate

\begin{tabular}{|l|c|c|}
\cline { 2 - 3 } \multicolumn{1}{c|}{} & $\begin{array}{c}\mathbf{1 9 3 3} \\
\text { Census }\end{array}$ & $\begin{array}{c}\mathbf{1 9 5 0} \\
\text { Census }\end{array}$ \\
\hline Population of Al-Hoceima & 6,941 & 10,770 \\
\hline Total urban population & 95,000 & 246,389 \\
\hline $\begin{array}{l}\text { Total population Spanish } \\
\text { Protectorate }\end{array}$ & 697,211 & $1,082,009$ \\
\hline
\end{tabular}

Source: Compiled by the author. BOP Año XXIII, 36, 1935 (pp. 1557-1558, 1561-1562). Comisión Histórica de las Campañas de Marruecos, 1935, volume I (p. 145). Comisión Histórica de las Campañas de Marruecos, 1936, volume I (pp. 186-187).

The Spanish emigrated with their nuclear families, which benefited their long-term integration and at the same time encouraged a daily routine similar to that of any city on the peninsula, with people of various generations and different social classes living there. As my interviewee Pepe recalled, "In Alhucemas" ${ }^{8}$, social class was clearly defined. There were military personnel, merchants ... middle class business people ... and fishermen". Moroccans never appeared in Pepe's description even though they would have visited the city every day to work.
The situation in Spanish Guinea was very different. The Spanish settlement was much smaller there, with restrictions placed on the initial arrival of women that were only gradually lifted, facilitating a degree of family reunification that was never fully realised. The scarcity of white women aggravated the abuse of black women, Miningas ${ }^{10}$, who had to put up with constant harassment by numerous Spaniards (Nerín, 1999). The situation was partially eased as the decades passed, as the number of Spanish women increased to reach a third of the total by the end of colonisation. For example, in 1942 there were 4,124 "white" people living in Spanish Guinea, of whom only 635 were women (see tables 6 and 7). Ten years later, in 1952, the number of women was 1,216 , while the total "white" inhabitants numbered 3,937".

Table 6. Breakdown of the "white" population of the Spanish Territories of the Gulf of Guinea in 1942

\begin{tabular}{|c|c|}
\hline \multicolumn{2}{|c|}{ Total: $\mathbf{4 , 1 2 4}$} \\
\hline $\mathbf{3 , 4 8 9}$ men & $\mathbf{6 3 5}$ women \\
\hline 2,693 Spaniards & 375 Spaniards \\
114 Portuguese & 39 Portuguese \\
20 Germans & 5 Germans \\
17 Syrians & 4 Syrians \\
11 Italians & 1 Italians \\
2 French & 2 French \\
3 English & 1 English \\
20 others & 12 others \\
\hline
\end{tabular}

Source: Compiled by the author. Resúmenes Estadísticos del Gobierno General de los Territorios Españoles del Golfo de Guinea, 1945 (pp. 30-31).

Table 7. Population breakdown of "white" and "black" inhabitants of Bata City. 1942 Census

\begin{tabular}{|c|c|}
\hline \multicolumn{2}{|c|}{ Total: $\mathbf{8 4 8}$} \\
\hline 235 Europeans & 613 “indigenous" \\
\hline $171 \mathrm{men} / 64$ women & $431 \mathrm{men} / 182$ women \\
\hline
\end{tabular}

Source: Compiled by the author. Resúmenes Estadísticos del Gobierno General de los Territorios Españoles del Golfo de Guinea, 1949 (p. 29). Resúmenes Estadísticos Región Ecuatorial, Provincias de Fernando Póo y Río Muni, 1963 (p. 460). Anuario Estadístico de España, 1969, p. 456.

Once there, few Spanish settlers contemplated bringing their families, preferring instead to return to the peninsula for long periods, taking advantage of contracts that allowed them six months of holiday for each year and a half worked, as was the case for Ramon Reig ${ }^{12}$. In contrast to Al-Hoceima, where the Spanish sources do not mention the Moroccans, in Spanish Guinea constant references are made to African populations due to their dependence on them for the success of their plantations. For example, Ramon's wife, Irmina, who was living in Oveng, explained in one letter that the crisis was especially hard for Equatorial Guineans after Spanish Civil War, re- 
ferring to them as "Morenos", the politically "correct" Spanish way to refer to them until the 1960s. She wrote in 1943 that, "Upon returning ... things are very changed, there is little food ... Morenos do not want money but goods ..."

To a certain degree, many colonial locations were mirrors of Spanish society. In Al-Hoceima this was notable in structural issues such as the rigidity between social classes visible in certain leisure spaces but not others. The prevailing Spanish gender construction in both Spanish Guinea and the Spanish Protectorate also encouraged Spanish women to be housewives and wives (Nash 1991), prioritising the study of their labours. In Spanish Guinea Francoist political pressure was also felt - albeit less strongly - from the female arm of the Falange in particular (Stucki, 2016, p. 344; 2019, p. 169). The accounts also reveal that in the Spanish Protectorate the postwar famine did not make much of a dent because foodstuffs such as butter and sugar that became scarce on the peninsula had little trouble arriving. There were also greater freedoms carnival, for example, which was banned in Spain, could be regularly celebrated. But the Spanish sense of superiority was always there. As Pepe explained, without empathy, "Spaniards did not do precarious work. We were carpenters, masons, plumbers ... But living together was inconceivable given our cultural differences. Our preparation ... [and] standard of living was far superior to theirs". Their refusal to be classed as Moroccans was a clear sign of contempt. For Pepe, "In my days, you were Moor just for having been being born there. My brotherin-law in Alicante was called "el moro" (the Moor)! ... These people know nothing ... Being born there isn't enough to make you a Moor".

Spanish Guinea was more relaxed, although cities like Santa Isabel and to a lesser degree Bata had neither the same number of Spaniards nor the same social life as AlHoceima, meaning that their density and representativeness were not comparable. In fact, the first casino in the capital of Fernando Póo was opened by the African elite group, the Fernandinos, as the Spanish population had always been relatively small and was scattered across the plantations, complicating their leisure activities. The construction of gender among the Spanish middle classes in Spanish Guinea also became blurred when, facing the crisis caused by provincialisation (1959) and later by regional autonomy (1963), some Spanish women had to start working at the same time as Equatorial Guineans began their slow socio-political empowerment in the colony. Irmina Margenat was one such case. She went from being the wife of a manager and partner on the Hacienda Vírgen de Montserrat plantation in 1927 to opening a modest grocery store providing service and sales to Equatorial Guineans in $1964^{14}$. On the other hand, Spanish Guinea's abundance and wealth kept their hopes of success and enrichment alive. This was visible when the Spanish returned to the peninsula for holidays with luxurious imported cars, unseen there, that they had bought in the Canary Islands. The image was of victorious colonisers, as they confirmed with stories of their adventures and lives. Their example might have encouraged the young if the colonial splendour had not burned out on the mainland in barely three decades with mixed benefits. Eduard $^{15}$, son of one of the owners of Hacienda Virgen de Montserrat, explained that his parents always imagined sending him to Spanish Guinea: "My brother, like me, forgot [the idea] after independence". In Al-Hoceima the situation was different because the wealth was not acquired from exploiting the land, but from providing services to the Spanish troops, officials and eventually people. This explains why the enrichment of the Spanish was also unequal and greater profits were guaranteed in Spanish Guinea than in the Spanish Protectorate. In fact, Aziza (2003, p. 258) categorises it as colonisation by the poor, referring to the Spanish who migrated to the region. But it is significant that the income disparities did not stop all the settlers, in either the Protectorate or the Spanish Territories of the Gulf of Guinea, from seeing their social class rise, including officials who moved in exchange for lucrative salary supplements that could be saved thanks to the low cost of life in the colonies.

The colonial process also had a direct impact on Riffian and Equatorial Guinean families, although in a different way. As I will show, while Riffian men and women were able to maintain their family unity even when working every day in Al-Hoceima, many Equatorial Guineans worked on plantations a long way from their villages and families, often against their will. As a result, many escaped, fleeing low pay, strenuous work, abuse and living conditions that were totally different from those in their villages. In both contexts, racialisation processes endorsed the exploitation of African populations and unequal salaries between Spaniards and Moroccans and Equatorial Guineans.

\section{SPANISH COLONISATION VERSUS AFRICAN EXPERIENCES}

Although the settlement of Spanish civilians in Santa Isabel and Bata had similar effects on their regions to AlHoceima's growth in the Rif, the Spanish colonisation of the Spanish Territories of the Gulf of Guinea was markedly rural in nature. The land use was based on a system of cocoa and coffee plantations and logging that led, on the one hand, to the Spanish population being dispersed and having limited urban life and, on the other, to the separation of the Equatorial Guinean population from their original settlements, as they were interned in facilities alongside Africans of other nationalities, and did not have permission to leave them or to visit family members. The majority of Spanish civilians did not appreciate that the work the Equatorial Guinean population carried out came close to forced labour, was poorly paid - if at all - and that it was performed alongside Nigerians and Liberians who, hired as labourers, had better wages and binding clauses that the landowners respected until the end of their contracts (see Table 8). Eduard says that "the Equatorial Guineans escaped at the first opportunity" because "they did not want to work". In her letters, Irmina seemed 
exhausted: "Every day, one is more disgusted with the conflicts that happen. The braceros (workers) are unbearable, looking for reasons not to work"16.

Table 8. Annual salary at Hacienda Virgen de Montserrat in 1959 (amounts in pesetas)

\begin{tabular}{|l|c|}
\hline "Indigenous" bracero & 2,600 \\
\hline Spanish plantation boss & 75,564 \\
\hline Spanish plantation manager & 96,000 \\
\hline
\end{tabular}

Source: Compiled by the author. Accounts of the Virgen de Montserrat Hacienda, Colección Giménez Ferrer (IMF-CSIC).

The colony's social organisation reflected a racial logic that ended up blurring the power differences between the settlers and in which the status of the white population was always higher than that of the black. In fact, the Equatorial Guineans, as a black African population, were down at the bottom of the social pyramid, divided between the non-emancipated and the partially emancipated $^{17}$, with the notable exception of the Fernandinos who, ${ }^{18}$ being such a small group based only in Fernando Póo, did not cause the racial boundaries to change for the rest of the country's black African population. The majority of Equatorial Guineans were therefore not emancipated and could not even sell goods, receive credit or appear as witnesses in court. Their rights regarding their capacity to own land (and here I am not referring to the emancipated, who already had special status) crucially changed after historical events as the provincialisation process of 1959 , the repeal of the emancipation law of 1960 and the autonomic period of 1963 , following nationalist opposition and international pressure on Spain ${ }^{19}$. These changes are notable in the NO-DO, where the empowerment of Equatorial Guineans at political level is visible in the invitation to visit a Spanish cruise liner of some "españoles de color" "20; in the Spanish Resúmenes Estadísticos del Gobierno General de los Territorios Españoles del Golfo de Guinea, which detail the increased production of the Equatorial Guinean cooperatives and the type of products they specialised in, despite the overall figures showing that the Africans could never compete with the Spanish plantations ${ }^{21}$ and that the colonial regime placed limits on their potential economic profits.

The colonisation of the Rif differed from that of Spanish Guinea for being urban rather than rural. The construction of a Spanish city like Al-Hoceima followed a distinct format: the Riffian population lived in small villages (douar) on the outskirts and began to sell their goods. Men and women sold basic products such as eggs, bread, vegetables and fruit and began to take advantage of the labour opportunities that $\operatorname{arose}^{22}$. As Merien recalled $^{23}$ " "[My father] began to work in Alhucemas at 14 years old. It was 1934 or 1935 ... He went there and back every day on foot ... It's almost $15 \mathrm{~km}$ ". Soumaya ${ }^{24}$ went a couple of times a week to sell eggs from her hens and often recalls playing in the patio of her house with her cousin Khalima ${ }^{25}$. This was in the early 1930s. In fact, the subtle economic differences between the two families shaped their futures, and show the similarities and differences that existed between Riffian women. Neither studied, and although Khalima's husband taught her basic notions of grammar so she could read, she forgot that learning and remains illiterate to this day. She never worked and after moving to Al-Hoceima in 1961, she spent many years without leaving home because her husband prohibited it, as her son proudly confirmed. Soumaya's life was very different. She always worked, first as a girl in the fields, loading wood, cutting wheat, taking care of chickens, cows, donkeys and sheep, work usually done by women in rural settings: "in those days there was neither water nor electricity in the countryside, not like now, with all of this". Soumaya explains that their poverty led her to work for the Spanish, first in a phosphate mine in 1949: "I dug, I removed earth and looked for phosphate. It was a very hard job! That was too much for me and after two years I quit" ${ }^{\text {"26. }}$. After leaving the job at the mine, Soumaya worked until 1957 in a canning factory in one of the Al-Hoceima's three salteries: "The Spanish said 'come on, come on' to get me to work faster. They didn't want us to get distracted or to stop too much. We worked long hours, from the night until the afternoon, although we were free at weekends". Soumaya was in the first group of Moroccan workers who lived in rented houses close to one of the barracks. She worked for six years at the saltery. Khalima's husband, $\mathrm{Abdel}^{27}$, studied in a madrasa, but Soumaya's, Mostapha ${ }^{28}$, was illiterate, and worked as a sewing machine mechanic. Abdel had more opportunities, though Mostapha's job was fairly good compared to far more precarious jobs such as stevedore (see Table 9). Riffian empowerment did not become a reality until independence, with the exception of certain prominent people and those Riffians who had entered the colonial administration in subordinate positions.

Table 9. Annual salary in urban contexts in Al-Hoceima and Tétouan in 1954 (amounts in pesetas)

\begin{tabular}{|l|c|}
\hline \multicolumn{1}{|c|}{ Employment } & Salary \\
\hline Moroccan fishing net repairer & 642 \\
\hline Moroccan service staff (waiter) & 3,000 \\
\hline Moroccan garbage collector & 3,744 \\
\hline Moroccan teacher & 14,929 \\
\hline Spanish teacher & 31,715 \\
\hline
\end{tabular}

Source: Compiled by the author. Boletín Oficial de la Zona de Protectorado Español en Marruecos, Año XLII, 49, 3rd December 1954, pp. 1707-1708. Boletín Oficial de la Zona de Protectorado Español en Marruecos, Año XLII, 51, 17th December 1954, p. 1801. For service staff salaries, see the interview with Pepe.

Taking advantage of the opportunities in Al-Hoceima, Abdel and Mostapha are good examples of the Riffians who benefitted from the city's construction. However, they are in no way representative of either all the Riffians 
who stood firm in the indigenous regiments (meha-las jalifianas), or the majority of Riffians who decided to resist colonial pressure from their villages, a long way from the new urban dynamics (Hart, 1976, p. 94). Abdel would end up working only for Arabs and Riffians. He translated Arabic texts, assisted with legal matters and worked as an Arabic teacher after independence, and managed to amass a number of properties. But Mostapha worked only for the Spanish. When his clientele departed, he had to reinvent himself as a mechanic for all types of motor, and managed to save enough to buy a house close to the old military hospital on the outskirts of Al-Hoceima.

\section{COLONIALITY AND SOCIAL PRACTICES IN SPANISH GUINEA AND THE SPANISH PROTECTORATE}

The overlap between Spanish coloniality and social practices seems fundamental to understanding how Spain usually recalls its Hispano-African colonial past. This brief account of the works and relationships of Equatorial Guineans and Riffians after the Spanish settlement revealed the hierarchy that existed between the Spanish and African populations in terms of labour rights, as in the Spanish Guinea and the Spanish Protectorate the local population constituted a cheap - when not free - workforce.

In Spanish Guinea, the Spanish believed that providing food for the braceros or workers on their land showed a level of appreciation for them, but in reality being fed was a right established by the colony's legislation, which set different wages according to whether food was provided or not (see Table 10). ${ }^{29}$ Then there were the great differences depending on whether a workforce came from Spanish Guinea or from other African countries ${ }^{30}$. For Eduard, the key problem was that the native population had everything it could need within reach, and that "there was no hunger there, and no need to work".

Table 10. Expenses listed under "Indigenous personnel". Hacienda Virgen de Montserrat in 1961 (amounts in pesetas)

\begin{tabular}{|l|c|}
\hline July-December medical retainer & 5,600 \\
\hline Epiphany party expenses & 640 \\
\hline Pharmacy & 1,203 \\
\hline Bracero transport & 48 \\
\hline Rationing & 6,605 \\
\hline Bundles of fish & 11,475 \\
\hline Extra pay coffee jobs & $2,588.25$ \\
\hline Healer advance & 1,600 \\
\hline
\end{tabular}

Source: Compiled by the author. Accounts of the Virgen de Montserrat Hacienda, Colección Giménez Ferrer (IMF-CSIC).

In the Rif, the workers who were employed by the Spanish entered the wage economy. Indeed, for Aziza (2003, p. 63) this was one of the clearest effects of the Spanish colonisation. Receiving a wage permitted certain improvements and even the possibility of saving to buy a house in the city, although as the wages were very low and the contracts verbal they did not protect the worker, as evidenced by the jobs in the mines, in the salteries, in the repair of sewing machines and in the services sector. For example, Riffian waiters received a symbolic daily wage because they worked on commission: $20 \%$ was divided between the two or three Riffian waiters working in an establishment. Pepe recalled that "the Moors who worked at home all had verbal contracts: I'm not coming, don't come!", although one ended up living with them and slept in the attic "on a mattress that was there, because in exchange he enjoyed the advantages of urban housing". In the douar the living conditions meant no electricity or running water, while the housing in Al-Hoceima provided greater comfort even though it took them away from their traditional means of subsistence (livestock husbandry and harvesting $)^{31}$. They did not have to walk 15-20 kilometres a day or sleep curled up on a landing in order not to lose their job, as they were woken in the morning by icy buckets of water thrown by an unkind Spanish neighbour (Aixelà-Cabré, 2019a, p. 863). Below, in Table 11, which corresponds to the budget of Al-Hoceima, we can see the different services the city provided, as compared to the precariousness of rural life.

Table 11. Budget of the Municipal Board of Al-Hoceima in 1936 (in pesetas)

\begin{tabular}{|l|c|}
\hline General obligations & $33,221.85$ \\
\hline Municipal representation & 2,360 \\
\hline Surveillance and security & 28,400 \\
\hline Urban police & 49,325 \\
\hline Administration and collections & 8,700 \\
\hline Central offices & 26,640 \\
\hline Public health and hygiene & 22,900 \\
\hline Healthcare and charity & 36,588 \\
\hline Public culture & $4,250.50$ \\
\hline Public works & $93,450.60$ \\
\hline Promotion of communal interests & 3,750 \\
\hline Unforeseen expenses & 3,000 \\
\hline Debits of the board & $29,237.90$ \\
\hline Total & $341,823.35$ \\
\hline
\end{tabular}

Source: Compiled by the author. BOP Año XXIII, 36, 1935 (pp. 1561-1562).

As in other colonial contexts, the moral and cultural superiority the metropole conferred on the Spanish was a major obstacle to the respect for the African population and the emergence of egalitarian relations. So much so that the devaluing of the occupied populations in the Spanish imaginary was promoted by the propaganda of the Spanish civilising mission (Stucki, 2019, p. 217), which is easily visible in many of the Spanish govern- 
ment's NO-DO recordings. The disparagement of the indigenous population took place both in the Spanish Protectorate and in the Spanish Territories of the Gulf of Guinea, although it was worse in the latter. Multiple statements describe the "Spanish superiority over the natives" 32 , a significant feature because it justified a status quo that refused to empower the colonies' inhabitants (Fernández, 2018, p. 71). In the case of Spanish Guinea, the anecdotes ended up confirming people's incapacity or childishness (Sánchez Gómez, 2006). For example, the Equatorial Guinean José Luís lamented that "the idea was repeated that the blacks did not want to work, without taking into account that many Equatorial Guineans found themselves obliged to engage in forced labour" ${ }^{\prime 3}$. Many Spaniards such as Eduard repeated that the Africans needed watching on the plantation "because if not they would sit down and not work". Among the stories that circulated to ridicule the Equatorial Guineans were those of a bracero breaking a machine because instead of putting oil on the machine "he put it all over his body" and a Spanish foreman's amazement at continually being asked for his shoes, "because they were not appropriate ... as well as their feet being too small ... Equatorial Guineans put them on ... and they couldn't walk". The stock of anecdotes about the eccentric behaviour of the Equatorial Guineans and Riffians confirmed their childishness and above all contributed to the devaluing of their culture and work and encouraged their subordination ${ }^{34}$. Nevertheless, without their unpaid or badly paid work, the colony would have lost its profitability and above all some of the symbolic essence that preserved Spanish superiority in the colonial narrative. In the eyes of José Luís, the indignity was too much when some Equatorial Guinean men were made to join the staff of the recently arrived Spaniards: "Indeed, there was no greater humiliation for a Fang man than dedicating themselves to domestic service" 35 . Soumaya also bore serious grievances towards the Spanish, although she did not express them when asked how she was treated, perhaps because she was being asked by a Spaniard. After a long, meaningful silence, eyes rising and falling with the weight of her advanced age, she said that "there were good Spaniards and bad Spaniards. There were all sorts". This seems to have been courtesy given the only two words of Spanish she remembered provide evidence of her relationship with her bosses: "Come on, come on" and "work, work" 36 . Her testimony fell a long way short of the rhetoric of Hispano-Moroccan brotherhood.

Ultimately, the Spanish showed a profound lack of knowledge of the peoples in the colonies. In the Rif, Pepe recalled that "we didn't have the slightest interest in learning; we didn't pick up more than 20 words in total". In Spanish Guinea, the few Spaniards who perceived certain differences among the black African population wondered why "the Equatorial Guineans always tried to escape from the plantations, while the African braceros did not". These examples show the Spanish lived in these places as in a conquered territory, with complete disinterest for the difficulties and injustices that the Riffian and Equatorial Guinean populations suffered.

\section{POSTCOLONIAL MEMORIES: LOOKING BACK, LOOKING AHEAD}

Reviewing the compensation the Riffian Moroccans and Equatorial Guineans received when independence came is disheartening. For example, co-owner and foreman of the Hacienda Virgen de Montserrat, Ramón Reig, recognised in 1965 that while the only Fang worker who been on the plantation since it opened in 1927 would be dismissed with regret, they would be "issued only with the compensation determined by the law", which was very little ${ }^{37}$. In fact, the partners kept the property until they regularised it in 1996, hoping to receive compensation for their hasty departure from the country, either from the Spanish government or the Equatorial Guinean, but it did not even occur to them to give a hectare to this elderly Fang man in recompense for so many years of loyalty. For her part, Merien angrily recalled how after so much dedication to his bosses, her father was left without rights: "When he was already elderly, I accompanied my father to Nador, to the Spanish consulate, to see whether having worked all his life for Spaniards he would receive any money. But though he had all the papers, they told him all the companies had closed. He had worked for many years ... he had suffered a lot, a lot, but nothing!"

But one of the most relevant issues is that the majority of former Spanish settlers did not question the colonisation. It is likely that the Spanish population, knowing that its country had overseas territories, did not either. Colonial illegitimacy was not even raised, nor was it on the conscience of many of those who returned to Spain after the independences. Eduard recalled the resistance of Ramón Reig and Irmina Margenat to returning to Spain: he experienced it as emotional blackmail, as they said "we are breaking our backs on the estate. We are not going to close". Only at the end did Ramón recognise that they should close the plantation and thereby "bring our adventure in Guinea to an end"38. Pepe did not even consider that colonialism was illegitimate despite having to flee from Al-Hoceima, and he complained that if they had to leave it was Spain's fault, which had abandoned the colony and the Spaniards.

On the other hand, the colonial period left Moroccans and Equatorial Guineans with residual identities that not all addressed in the same way. While the majority shared in the rejection of colonisation, after independence there was always a minority that longed for their relationship and status with the Spanish. Merien recalled how her father always said "I am Spanish!! I am not a Moor, I am Spanish". Or even "I am not an Arab!!! I am Muslim but not Spanish". In contrast, many Spaniards who were born in the protectorate saw it as a disadvantage that their identity cards stated that they were born in Al-Hoceima or Tétouan. For María, "the Moors have such a bad reputation around here, that we don't want to have been born there!"39. Asked about her opinion of Al-Hoceima, Maria's answer was that "Alhucemas is no fun now because there are so many Moors!" 
After these Spaniards returned, the migration began of Riffians and Equatorial Guineans to Spain, to their metropole, to live in a country that had not cultivated or sought a shared social history of its colonial past in Africa as shown by the episodes of xenophobia and racism to which they have been subjected - and where no attention has been given to common ties or colonial debts. Begoña's experience illustrates the Spanish unease: after receiving one particularly rude comment, she retorted that she was "a black Spaniard" 40 .

\section{CONCLUSION}

This article has reviewed Spain's colonialities and colonial practices in Spanish Guinea and in the Riffian city of Al-Hoceima through experiences and memories with the aim of verifying their versions of the colonial past to facilitate a more shared Hispano-African colonial history. The contrasting of Spanish oral memories with those of Riffians and Equatorial Guineans with the support of documentary and statistical data has been crucial to establishing their differences, evidencing how coloniality worked. The Spanish voices coincide with the colonial rhetoric, which, it has been noted, survives today in Spain thanks to the state's silence about its colonial past in Africa.

Decolonising Hispano-African narratives is urgent because the voices that experienced colonial times are dying out and the Riffian and Equatorial Guinean memories have been left out of the contemporary Spanish narrative. Contrasting them with those of the Spanish proves the existence of parallel memories without points of contact between them. This underlines the need to review the shared past from a Postcolonial and Decolonial point of view in order to make way for a more shared social colonial history that is plural and capable of taking on colonial debts and jettisoning racialized discourses constructed to justify inequalities.

\section{ACKNOWLEDGEMENTS}

This work was supported by the Research and Development Project 'African Memories: Reconstructing Spanish Colonial Practices and their Imprint in Morocco and Equatorial Guinea. Towards a Spanish-African Cultural Heritage' (2016-2018) (HAR2015-63626-P, MINECO/FEDER, UE), and by the Project Europa Investigación 'Enriching European Cultural Heritage from Cultural Diversity and Collaborative Participation' (20172018) (EUIN2017-85108), both from the Ministry of Economy-Competitiveness of Spain, and both directed by Aixelà-Cabré. The article was translated by Tom Hardy.

\section{ARCHIVES CONSULTED}

Archivo General de la Administración (Alcalá de Henares), Fondo África.

Biblioteca Virtual de Prensa Histórica: Boletín Oficial del Protectorado, 1925, 1935, 1937, 1940-1942, 1945, 1950, 1954-1956.
Colección Giménez Ferrer, Institució Milà i Fontanals (IMF-CSIC). This archive contains the documentation of the Hacienda Virgen de Montserrat coffee plantation in Oveng-Bata (mainland region of Spanish Guinea), which was established in 1927. The collection includes more than a hundred letters from Ramón Reig and Irmina Margenat written from Bata and Oveng, as well as numerous company documents such as balance sheets, participations and notarial documents, among others.

Filmoteca española: NO-DO on Al-Hoceima and Bata.

Resúmenes Estadísticos de los Territorios Españoles del Golfo de Guinea (from 1942 to 1964). Institució Milà i Fontanals (IMF-CSIC).

\section{NOTES}

1 Santos and Meneses's central idea of Epistemologies of the South $(2014$, p. 16) "is that along with all the dominations for which it is known, colonialism has also been an epistemological domination, an extremely unequal knowledge-power relationship that has led to the suppression of many forms of knowledge characteristic of colonised peoples and/or nations. The Southern epistemologies are the whole set of interventions that denounce this suppression, value the knowledge that successfully survived and investigate the conditions of a horizontal dialogue between knowledges".

2 I recommend the work of Schroeter (2018, p. 1158). In his text the author reflects on the way "the Holocaust and its memory have been exploited politically by Israel".

3 Almost every year, magazines such as Memory [16 (3) 2008 / 23 (1) 2015] and Memory Studies [1 (1) 2008 / 6 (1) 2013] devote special issues to the debate on memory, its compilation, uses, connections with oral history, and its capacity for collective representation, among other themes. The contribution of Assmann (2008) should be highlighted, who proposed a textuality of the past, creating the field of "mnemohistory" because he understood history to be a form of remembering.

4 For more on the impact of Spanish colonial rhetoric on Equatorial Guineans migrants, see Yolanda Aixelà-Cabré, "The Presence of the Colonial Past: Equatorial Guinean Women in Spain", Itinerario. Journal of Imperial and Global Interactions, 44 (1): 140-158. The work of Moreras (2018) is recommended on the colonial narrative on Moroccans in Spain,

5 Spanish Guinea was called "Spanish Territories of the Gulf of Guinea" before 1926. After colonial independence, the name was changed to Equatorial Guinea.

6 The contested celebration of the fifth centenary of the Spanish discovery of America held in 1992 was renamed "Encounter between two worlds" due to Mexican influence (Rodríguez, 2011, p. 68). The lateness of this proved the lack of Spanish interest in critically revisiting its imperial past. Indeed, self-criticism of its legacy in America was forgotten in the promotion of the Marca España (Spanish Brand) by the Spanish state in 2012, which explicitly mentioned "the discovery of America" as a Spanish merit, disregarding Latin American first people's criticism.

7 In 1933, the city already had 6,941 inhabitants; in 1950, there were 10,770. Figures available at Boletín Oficial del Protectorado, Año XXIII, 36, 1935 (pp. 1557-1558, 1561-1562), and Comisión Histórica de las Campañas de Marruecos (1935, p. 145).

8 The Spanish referred to Al-Hoceima as Alhucemas, Villa Sanjurjo, or Villa. For more information about its naming, see Aixelà-Cabré $(2019 \mathrm{~b}, \mathrm{p} .70)$.

9 Pepe was born in Melilla in 1931 and lives in Almería. His parents were among the first Spanish civilians established in Al- 
Hoceima. He left Morocco in 1957 and never returned. Different conversations from Almería from 2015 to 2018.

10 Miningas was how the Spanish referred to their Equatorial Guinean lovers.

11 Resúmenes Estadísticos del Gobierno General de los Territorios Españoles del Golfo de Guinea (1958, p. 36). I reproduce the Spanish categories used in this source to racialize the cultural difference in the Spanish Territories of the Gulf of Guinea: "white" and "black"

12 Ramón Reig worked in Hacienda Virgen de Montserrat with his wife, Irmina Margenat. He owned part of this coffee plantation. More information at Colección Giménez Ferrer, IMF-CSIC. The Colección Giménez Ferrer is composed of 73 legal papers, different notarial demands and balance sheets, 198 personal and business letters, nine photographs, and eight personal documents. The information has been compared with that of Eduard Giménez Ferrer, who gently reconstructed the conversations maintained by his parents and the Reig family.

13 Irmina Margenat. Letter from Oveng-Bata of March 2, 1943. Colección Giménez Ferrer, IMF-CSIC

14 Irmina Margenat. Letter from Bata-Oveng of June 14, 1944. Colección Giménez Ferrer, IMF-CSIC. According to Eduard Giménez Ferrer, Irmina opened a shop with a friend to get rich in 1944, but the business soon closed.

15 Eduard Giménez Ferrer was born in Barcelona in 1939. His parents were co-owners of a coffee plantation in Oveng, Bata district, Equatorial Guinea. Owner of the Collection GiménezFerrer, ceded to Institució Milà i Fontanls del CSIC (Barcelona). Interviewed several times in Barcelona from 2015 to 2020.

16 Irmina Margenat. Letter from Bata of November 27, 1957. Colección Giménez Ferrer, IMF-CSIC.

17 Ndongo is recommended for more in-depth information on the classification of this regulation (1977, pp. 57-58).

18 The Fernandinos were fully emancipated blacks. Full emancipation for the Fernandino minority arrived with the decree on September 30th 1944 that granted them equality with the white majority in terms of civil rights. On the emergence of the Fernandinos, Pélissier (1963, p. 627) may be consulted.

19 As Bolekia explains (2003, p. 90-91) "the Spanish Guineans (those from Spanish Guinea) are 'nationalised' Spanish and are granted the right to four hectares of land for the cultivation of cacao, coffee, yuca and other products for their own consumption".

20 See the NO-DO from February 27th 1961, NOT N 947 C.

21 Resúmenes Estadísticos del Gobierno General de los Territorios Españoles del Golfo de Guinea (1947, p. 80-82).

22 See the NO-DO from April 3rd 1944, NOT N 66 B, in which you can see Riffians selling a range of products in the Alcazarquivir market.

23 Merien is 50 years old. She was born in Al-Hoceima (Morocco) in 1967. She has lived in Barcelona province since 1998 and travels once a year to visit her mother in Al-Hoceima. Interviewed in various locations in the province of Barcelona since 2002.

24 Soumaya was born in Einsolen (Morocco) in 1932. She is 85 years old. She is the mother of Merien and mother-in-law of Hamid. Interviewed in Al-Hoceima in September 2016.

25 Khalima was born in Einsolen (Morocco) in 1928 and lives in Al-Hoceima. Interviewed in Al-Hoceima in September 2016.

26 Aixelà-Cabré (2019a, p. 864; 2019b, p. 97).

27 Abdel was born in Einsolen in 1914. He studied Arabic and worked in Al-Hoceima until he died.

28 Mostapha was born at Einsolen (Morocco) in 1922. He died in Al-Hoceima in 2016, at the age of 94 years old.

29 Resúmenes Estadísticos del Gobierno General de los Territorios Españoles del Golfo de Guinea (1955, p. 214).

30 Resúmenes Estadísticos del Gobierno General de los Territorios Españoles del Golfo de Guinea (1955, pp. 212, 215-216).

31 In different NO-DOs you can see the peculiarities of the small rural communities in the Rif, compared to the city of Al-Hoceima. These recordings were intended to show the parades that the Spanish organized on emblematic dates or for the visit of some high-ranking official. See the NO-DO from October 20th
1952, NOT N 511 B, military parade in Villa Sanjurjo and other images of the Rif. To see other cities or rural areas, see the NODO from April 30th 1945, NOT N122 B. in which Tétouan appears, or the NO-DO from June 17th 1946, NOT N 180 B, showing rural areas as a parade passes. For an analysis of the meaning of the military parades in the Moroccan and Equatorial Guinea colonies, see Aixela-Cabré (2019b).

32 The NO-DO from November 17th 1958, NOT N 828 A. recorded in the city of Bata allows us to see the tribute to a missionary at the Bata Delegation of Indigenous Affairs. The white minority appears seated next to the authorities while the black African population had to gather and observe the event on foot.

33 José Luís was born in Bata district (Equatorial Guinea) in 1958. $\mathrm{He}$ is a lawyer and lives in Barcelona. Several interviews conducted in Barcelona since 2011.

34 Fernández (2018, pp. 84-85) studied the "burla" as a native agency in opposition to colonial imposition. It was an attitude of resistance.

35 "Boy" was the name used for the Equatorial Guinean domestic employees who worked for the Spanish.

36 Testimony cited by Aixelà-Cabré (2019a, p. 864; 2019b, p. 97)

37 Letter from Ramón Reig to Eduard Giménez, May 1965. Colección Giménez Ferrer, IMF-CSIC.

38 Ramon Reig. Letter from Bata-Hacienda Virgen de Montserrat of May 2, 1965. Colección Giménez Ferrer, IMF-CSIC.

39 María was born in Al-Hoceima (Morocco) in 1936, where she remained until the 1960s. She lives in Alicante. Interviewed in Alicante in May 2016.

40 Begoña is 48 years old and was born in Malabo (Equatorial Guinea). When she was nine years old she was exiled to Spain with her family due to political reasons. She lives in London, but previously lived in Madrid, Paris and Brussels. Interviewed in November 2009, January 2010, August 2016 and July 2018.

\section{REFERENCES}

Abrighach, Mohamed (2015) "Marruecos/España en la narrative española contemporánea”. Boletín Hispánico Helvético, 26, pp. 121-151.

Aixelà-Cabré, Yolanda (2017) "Exploring Euro-African pasts through an analysis of Spanish colonial practices in Africa (Morocco and Spanish Guinea)". Canadian Journal of African Studies / La Revue canadienne des étudesafricaines, 51 (1), pp. 23-42. DOI: 10.1080/00083968.2016.1276848

Aixelà-Cabré, Yolanda (2018) The Management of Religious, Ethnic and Cultural Diversity in Europe in the 21th Century. New York, Lewinston: Edwin Mellen.

Aixelà-Cabré, Yolanda (2019a) "Colonial Memories and Contemporary Narratives from the Rif. Spanishness, Amazighness and Moroccaness seen from Al-Hoceima and Spain". Interventions. International Journal of Postcolonial Studies, 21 (6), pp. 856873. DOI: 10.1080/1369801X.2018.1558093

Aixelà-Cabré, Yolanda (2019b) Ciudades, glocalización y patrimonio contestado. Una historia de Bata y de Al-Hoceima, 19002019 (Guinea Ecuatorial y Marruecos). Barcelona: Edicions Bellaterra.

Álvarez Chillida, Gonzalo and Martín Corrales, Eloy (2013) "Haciendo patria en África. España en Marruecos y en el Golfo de Guinea”. In: J. Moreno and X. M. Núñez, ed., Ser españoles. Imaginarios nacionalistas en el siglo XX. Madrid, RBA, pp. 399-432.

Assmann, J. (2008) "Communicative and Cultural Memory". In: Erll, A. and Nünning, A. (eds.), Cultural Memory Studies. An International and Interdisciplinary Handbook. Berlin: Walter de Gruyter, pp. 109-118

Aziza, Mimoun (2003) La sociedad rifeña frente al Protectorado español de Marruecos (1912-1956). Barcelona: Bellaterra.

Bolekia, Justo (2003) Aproximación a la historia de Guinea Ecuatorial. Salamanca: Amarú ediciones.

Borst, Julia, and Gallo González, Danae (2019) "Narrative Constructions of Online Imagined Afro-diasporic Communities in 
Spain and Portugal". Open Cultural Studies, 3, pp. 286-307. DOI: https://doi.org/10.1515/culture-2019-0026

Buettner, Elisabeth (2016) Europe after Empire: Decolonization, Society and Culture. Cambridge: Cambridge University Press.

Boum, Oumar (2013) Memories of Absence: How Muslims Remember Jews in Morocco. Stanford, CA: Stanford University Press.

Castro-Gómez, Santiago y Grosfoguel, Ramón (2007) "Prólogo. Giro decolonial, teoría crítica y pensamiento heterárquico". In Castro-Gómez, S. and Grosfoguel, R. (comp.) El giro decolonial: reflexiones para una diversidad epistémica más allá del capitalismo global. Bogotá: Siglo del Hombre Editores, pp. 9-23.

Comisión Histórica de las Campañas de Marruecos (1935) Geografía de Marruecos, Protectorados y Posesiones de España en África. Madrid: Imprenta del Ministerio de la Guerra. Vol I.

Delgado, Luisa Elena (2014) La Nación Singular. Madrid: Siglo XXI

Evans-Pritchard, E. E. (1961) Anthropology and History. Manchester: Manchester University Press.

Fernández, Nuria (2018) "Colonial Discourse and Native Resistance. The Evangelization of Bioko Island in the Early 20th Century (Equatorial Guinea)". In: Aixelà-Cabré, Y. (ed.) In the footsteps of Spanish colonialism in Morocco and Equatorial Guinea. Zurich: Lit Verlag, pp. 71-99.

Fernández Parrilla, Gonzalo (2006) La literatura marroquí contemporánea: la novela y la crítica literaria. Cuenca: Ediciones de la Universidad de Castilla-La Mancha.

Fernández Parrilla, Gonzalo and Cañete, Carlos (2019) "SpanishMaghribi (Moroccan) relations beyond exceptionalism: a postcolonial perspective". The Journal of North African Studies, 24 (1), pp. 111-133. DOI: 10.1080/13629387.2018.1459262

Goody, Jack (2007) The Theft of History. Cambridge: Cambridge University Press.

Hart, David Montgomery (1976) The Aït Waryaghar of the Moroccan Rif. An Ethnography and History. Arizona: Wenner-Gren Foundation for Anthropological Research Inc., University of Arizona Press.

Huyssen, Andreas (2007) En busca del futuro perdido. Cultura y memoria en tiempos de globalización. Buenos Aires: Fondo de Cultura Económica.

Iliescu Gheorghiu, Catalina (2017) "Equatorial Guinean Migrants in Spain. An Analysis of Implicit Discourse”. Hispanófila, 181, pp. 169-189.

Jelin, Elizabeth (2002) Los trabajos de la memoria. Madrid: Siglo XXI.

Kamen, Henry (2006) Del imperio a la decadencia. Los mitos que forjaron la España moderna. Madrid: Ediciones Temas de Hoy.

Lee, Cristopher J. (2005) "Subaltern Studies and African Studies". History Compass, 3, pp. 1-13.

López García, Bernabé (2007) "El olvido del exilio para los españoles en el norte de África. La investigación sobre el exilio y la emigración de los españoles de Marruecos". In: López García, B. and Hernando de Larramendi, M. (eds.) Historia y memoria de las relaciones hispano-marroquies: un balance en el cincuentenario de la independencia de Marruecos. Madrid: Ediciones del Oriente y el Mediterráneo, pp. 176-205.

López García, Bernabé (2008) "Españoles en Marruecos. Demografía de una historia compartida". In: Lahrech, A, and Benlabbah, F. (eds.) Españoles en Marruecos: 1900-2007: historia y memoria popular de una convivencia. Rabat: Bouregreg, pp. 17-48.

Lorcin, Patricia M. E. (2014) "France's Nostalgias for Empire". In: E. Chabal, ed., France since the 1970s. History, Politics and Memory in an Age of Uncertainty. London: Bloomsbury, pp. 143-171.

Marcus, George E. (1995) "Ethnography In/Of the World System: the Emergence of Multi-Sited Ethnography". Annual Review of Anthropology 24, pp. 95-117.

Martín Corrales Eloy (2002) La imagen del magrebi en España. Barcelona: Bellaterra.

Martín Corrales, Eloy (2008) "La marroquinización de una ciudad colonial española: Alhucemas, 1925-1956”. In: González Al- cantud, J. A. (ed.) La ciudad magrebí en tiempos coloniales: invención, conquista y transformación. Barcelona: Anthropos, pp. 201-231.

Martín Márquez, Susan (2011) Desorientaciones. El colonialismo español en África y la performance de identidad. Barcelona: Bellaterra.

Martínez Carreras, José Urbano (1993) África subsahariana, del colonialismo a la descolonización. Madrid: Síntesis.

Mateo Dieste, Josep Lluís (2003) La hermandad hispano-marroquí. Politica y religión bajo el Protectorado español en Marruecos (1912-1956). Barcelona: Bellaterra.

Mbare Ngom, Faye. (1996) Diálogos con Guinea. Panorama de la literatura guineoecuatoriana de expresión castellana a través de sus protagonistas. Madrid: Labrys.

Mignolo, Walter (2004) "Os esplendores e as miserias da "ciencia: colonialidade, geopolitica do conhecimento e pluriversalidade epistémica". In: Santos B. S. (ed.), Conhecimento prudente para uma vida decente: "Um discurso sobre as ciências» revisitado. Sao Paulo: Cortez Editora, pp. 667-709.

Mignolo, Walter (2018) "The Decolonial Option". In: Mignolo, Walter and Walsh, Catherine E., On Decoloniality: Concepts, Analytics, Praxis. Durham: Duke University Press, pp. 105245.

Moreras, Jordi (2018) "Legacies of Domination. A comparison of the Control of Islamic Rituals during the Spanish Protectorate in Morocco and the Shaping of a Spanish Islam. In: AixelàCabré, Y. (ed), In the Footsteps of Spanish Colonialism in Morocco and Equatorial Guinea. The Handling of Cultural Diversity and the Socio-Political Influence of Transnational Migration". Zürich: Lit Verlag, pp. 237-268.

Mudimbe, Valentin Yves (1988) The Invention of Africa: Gnosis, Philosophy, and the Order of Knowledge. London: James Currey.

Nerín, Gustau (1999) Guinea Equatorial. Història en blanc i negre. Barcelona: Empuries.

Nash, Mary (1991) "Pronatalismo y maternidad en la España franquista". In: Bock, G. and Thane, P (eds.) Maternidad y politicas de género. Madrid: Ediciones Cátedra/Universitat de València / Instituto de la Mujer, pp. 279-307.

Nerín, Gustau. (2019) Guinea. El franquisme colonial. Barcelona: Memorial Democràtic de la Generalitat de Catalunya.

Ndongo, Donato (1977) Historia y tragedia de Guinea Ecuatorial. Madrid: Editorial Cambio 16.

Ndongo, Donato (2000) Literatura de Guinea Ecuatorial. Madrid: Casa de Africa-Sial.

Ndongo, Donato (2010) "La literatura de Guinea Ecuatorial 25 años después". In: Miampika, L. W. (ed.) La palabra y la memoria: Guinea Ecuatorial 25 años después. Madrid: Verdum, pp. 1937.

Otabela, Joseph-Désiré and Onomo-Abena, Sosthène (2009) Entre estética y compromiso. La obra de Donato Ndongo-Bidyogo. Madrid: UNED.

Pélissier, René (1963) "La Guinée Espagnola". Revue Française de Science Politique, 13 (3), pp. 624-644.

Quijano, Anibal (2014) "Colonialidad del poder y clasificación social”. In: Sousa and Meneses (eds.), Epistemologías del Sur (Perspectivas). Madrid: Akal, pp. 67-107.

Rizo, Elisa (2012) "Equatorial Guinean Literature in a Context of State-Promoted Amnesia". World Literature Today, 86 (5), pp. 32-36.

Rodríguez, Silvia Patricia (2011) "Conmemoraciones del cuarto y quinto centenario del ' 12 de octubre de 1492': debates sobre la identidad americana". Revista de Estudios Sociales, 38, pp. 6475.

Rodríguez Mediano, Fernando (1999) "Delegación de Asuntos Indígenas, S2N2. Gestión racial en el Protectorado Español en Marruecos". Awraq, 20, pp. 173-206.

Roman, Juan (1994) Fragmentos de una conversación continua sobre Alhucemas. Melilla: Ayuntamiento de Melilla, Servicio de Publicaciones.

Rubio Alfaro, Plácido, and Lacalle Alfaro, Santiago (1992) Alhucemas en mi recuerdo Ediciones: Málaga. 
Sahlins, Marshall (1993) "Goodbye to Tristes Tropes: Ethnography in the Context of Modern World History". Journal of Modern History, 65 (1), pp. 1-25.

Salafranca, Jesús F. (2001) El sistema colonial español en África. Málaga: Editorial Algazara.

Sánchez Gómez, Luís Ångel (2006) "África en Sevilla: la exhibición colonial de la Exposición Iberoamericana de 1929". Hispania, LXVI, 224, pp. 1045-1082.

Santamaría Colmenero, Sara (2018) "Colonizar la memoria. La ideología de la reconciliación y el discurso neocolonial sobre Guinea Ecuatorial”. Journal of Spanish Cultural Studies, 19 (4), pp. 445-463. DOI: 10.1080/14636204.2018.1524994

Schroeter, Daniel (2018) "Islamic Anti-Semitism" in Historical Discourse". The American Historical Review, 123 (4), pp. 1172-1189.

Schroeter, Daniel (1988) Merchants of Essaouira. Urban society and imperialism in southwestern Morocco, 1844-1886. Cambridge: Cambridge University Press.

Schroeter, Daniel (2002) The Sultan's Jew: Morocco and the Sephardi World. Palo Alto: Stanford University Press.

Sousa Santos, Boaventura de and Meneses, María Paula. 2014. "Introducción". In: Sousa, B. and Meneses, M. P. (eds.), Epistemologías del Sur (Perspectivas). Madrid: Akal, pp. 7-16.
Spivak, G. C. (1988) “Can the subaltern speak?” In: Nelson, C. and Grossbergm L. (ed.), Marxism and the Interpretation of Culture. London: Macmillan, pp. 271-313.

Stoler, Ann Laura (2002) "Colonial archives and the Art of Governance". Archival Science, 2, pp. 87-109.

Stoler, Ann Laura, and Karen Strassler (2000) "Castings for the Colonial: Memory Work in 'New Order' Java". Comparative Studies in Society and History, 42 (1), pp. 4-48.

Stucki, Andreas (2016) “¿Españolizar desde la raíz? La formación de una élite femenina de cooperación en el "pequeño imperio español', c. 1960-1975". Journal of Spanish Cultural Studies, 17 (4), pp. 343-360

Stucki, Andreas (2019) Violence and Gender in Africa's Iberian Colonies. Feminizing the Portuguese and Spanish Empire, 1950s-1970s. Switzerland: Palgrave Macmillan.

Thompson, Paul (1988) La voz del pasado. La historia oral. Valencia: Edicions Alfons el Magnanim.

Vansina, Jan (1961) De la tradition orale. Essai de méthode historique. Tervuren: Musée Royal de l'Afrique Centrale.

Walsh, Catherine E. (2018) "Decoloniality in/as Praxis". In: Mignolo, W. D. and Walsh, C. E., On Decoloniality: Concepts, Analytics, Praxis. Durham: Duke University Press, pp. 15-102. 